\title{
Hexamermis paranaense new species (Nematoda, Mermithidae): a parasite of Diloboderus abderus (Coleoptera, Scarabaeidae) in Argentina
}

\author{
María Fernanda Achinelly ${ }^{1} \&$ Nora Beatriz Camino ${ }^{2}$ \\ 1. Centro de Estudios Parasitológicos y de Vectores, CEPAVE, Calle $2 \mathrm{~N}^{\circ}$ 584, La Plata, Argentina; CONICET. \\ (fernanda@museo.fcnym.unlp.edu.ar) \\ 2. Investigador CIC.
}

\begin{abstract}
A new species, Hexamermis paranaense n. sp. (Nematoda, Mermithidae), a parasite of larvae of Diloboderus abderus Sturm, 1826 (Coleoptera, Scarabaeidae) is described and illustrated. This new species is characterized by amphids small, amphidial opening pocket-shaped, the anterior portion of the vagina muscularized and slightly protruding with a descending branch forming a loop before joining the uterus, and three rows of genital papillae: the ventrolateral divided in two rows with eight papillae in the outer row and with six papillae in the inner one; the ventral row with four pairs and one single preanal papillae, and with two pairs, a triplete, one pair, a single and one pair postanal papillae.
\end{abstract}

KEYWORDS. Hexamermis paranaense n. sp., Nematoda, Mermithidae, parasite, Scarabaeidae, Argentina.

RESUMEN. Hexamermis paranaense sp. nov. (Nematoda, Mermithidae): parasito de Diloboderus abderus (Coleoptera, Scarabaeidae) en Argentina. Una nueva especie, Hexamermis paranaense sp. nov. (Nematoda, Mermithidae), parásito de larvas del gusano blanco, Diloboderus abderus Sturm, 1826 (Coleoptera, Scarabaeidae), se describe e ilustra. Esta nueva especie se caracteriza por poseer anfidos pequeños, con la apertura en forma de bolsillo, parte anterior de la vagina muscular, con una rama que desciende y forma un lazo antes de la conexión al útero, tres hileras de papilas genitales: la hilera de posición ventro-lateral dividida en dos hileras con ocho papilas en la hilera externa y con seis papilas en la interna; la hilera ventral con una papila, seguida de cuatro pares, todas en posición preanal y dos pares, interrumpidos por tres papilas, seguida de un par, una simple, y un par, todas de posición postanal.

PALABRAS-CLAVE. Hexamermis paranaense sp. nov., Nematoda, Mermithidae, parasito, Scarabaeidae, Argentina.

The genus Hexamermis Steiner, 1924, has been extensively studied in plagues of agriculture (САмIMO \& Stock, 1989; Hernández-Crespo \& Santiago-Alvarez, 1997; PoInAR JR. \& ChANG, 1985; Wouts, 1981). At present five species have been isolated from Argentina, $H$. cochlearius Stock \& Camino, 1992, H. ovistriata Stock \& Camino, 1992, both in acridids; H. macrostoma Camino \& Stock, 1994, a parasite of crickets; H. hortensis Camino \& Stock, 1989, in Lepidoptera, noctuids; and $H$. gracilis de Villalobos \& Camino, 1998, parasitizing white grub. While conducting a field survey on horticulture pests in the area of Paraná, Entre Ríos, in Argentina we found some larvae of Diloboderus abderus Sturm, 1826 (Coleoptera, Scarabaeidae) which were parasitized by mermithid nematodes. They represented a new species described below under the name of Hexamermis paranaense $\mathrm{n}$. $\mathrm{sp}$.

\section{MATERIAL AND METHODS}

During October of 2002, larvae of D. abderus, were collected with a spade in the fields of horticulture in Paraná ( $31^{\circ} 50^{\prime} \mathrm{S}, 60^{\circ} 45^{\prime} \mathrm{O}$ ), Entre Ríos, Argentina. They were placed in cages containing plastic dishes with moist soil. After emerging from the host, the juvenile nematodes migrated into the moist soil where they matured to adults. Adults and postparasitic juvenile nematodes were observed alive and then killed by immersion in $60^{\circ} \mathrm{C}$ distilled water for $2 \mathrm{~min}$, fixed in TAF ( $7 \mathrm{ml}$ formalin, $2 \mathrm{ml}$ trietanolamine, and $91 \mathrm{ml}$ distilled water) and processed to glycerol by Seinhorst's method for taxonomic studies (CURRAN \& HoMinICK, 1980). Drawings and measurements were made from live and fixed specimens with a camera lucida microscope, and a light microscope. The range of the characters is given following by the mean value. Type material deposited in Museo de La Plata (MLP) and Colección Helmintológica del CEPAVE (CHC).

\section{Hexamermis paranaense $\mathbf{n}$. sp. (Fig. 1-8)}

Long white nematodes. Cuticle with criss-cross fibres visible with the light microscope. Head homocephalic. Six wide cephalic papillae surrounding the mouth. Stoma small and thin. Mouth terminal and central. Amphids small, amphidial opening pocket-shaped. Six hypodermal chords: lateral chords containing two rows of cells along the body, dorsal, subventral and ventral chords containing one row of cells. Vulva a longitudinal slit. Vagina "J" shaped, orientated at $90^{\circ}$ to the longitudinal body axis. Anterior portion of the vagina muscularized and slightly protruding with a descending branch forming a loop before joining the uterus. Spicules paired, medium sized, never exceeding the width of the body at anal level. Spicule tip simple and not sculptured. The genital papillae arranged in three double rows: the ventral lateral with eight papillae in the outer row and with six papillae in the inner one; the ventral row with four pairs and one single preanal papillae, and with two pairs, a triplete, one pair, a single and one pair postanal papillae. 
Allotype (female): Length $=8 \mathrm{~cm}$; head diameter at cephalic papillae level: $53 \mu \mathrm{m}$; body diameter at nerve ring level: $111 \mu \mathrm{m}$; maximum body diameter: $249 \mu \mathrm{m}$; body diameter at posterior end of trophosome: $128 \mu \mathrm{m}$; body diameter at vulva: $280 \mu \mathrm{m}$; distance anterior end to nerve ring: $289 \mu \mathrm{m} ; \mathrm{V}: 55 \%$; vagina length: $100 \mu \mathrm{m}$; vagina width: $84 \mu \mathrm{m}$.

Female (paratypes; $\mathrm{n}=20$ ): Length $=8-13,6 \mathrm{~cm}$ (10.86 \pm 2.8$)$; head diameter at cephalic papillae level: 35.2$54.05 \mu \mathrm{m}(43.75 \pm 9.55)$; body diameter at nerve ring level: 108.1-112 $\mu \mathrm{m}(110.03 \pm 1.95)$; maximum body diameter: 248 $252 \mu \mathrm{m}(250 \pm 2)$; body diameter at posterior end of trophosome: $100-200 \mu \mathrm{m}(140 \pm 52.91)$; body diameter at

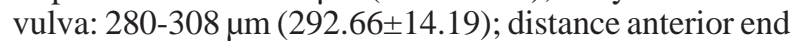
to nerve ring: $276-300 \mu \mathrm{m}(288.66 \pm 12.05)$; V: $54-55 \%$ (54.5 \pm 0.7$)$; vagina length: $92-120 \mu \mathrm{m}(104 \pm 14.42)$; vagina width: $60-90 \mu \mathrm{m}(78 \pm 15.87)$.
Holotype (male): Length $=7.1 \mathrm{~cm}$; head diameter at cephalic papillae level: $60 \mu \mathrm{m}$; body diameter at nerve ring level: $112 \mu \mathrm{m}$; maximum body diameter: $191 \mu \mathrm{m}$; body diameter at anus level: $204 \mu \mathrm{m}$; distance anterior end to nerve ring: $322 \mu \mathrm{m}$; tail appendage length: 38 ; spicule length: $193 \mu \mathrm{m}$; spicule width: $16 \mu \mathrm{m}(15.36 \pm 1.09)$.

Male (paratypes; $n=16$ ): Length $=6.8-7.3 \mathrm{~cm}$ (7.06 \pm 0.25$)$; head diameter at cephalic papillae level: 47 $60 \mu \mathrm{m}$ (53 \pm 6.56$)$; body diameter at nerve ring level: 100 $112 \mu \mathrm{m}(104 \pm 6.93)$; maximum body diameter: $172-192 \mu \mathrm{m}$ (181.33 \pm 10.07$)$; body diameter at anus level: $190-248 \mu \mathrm{m}$ (214 \pm 30.26$)$; distance anterior end to nerve ring: $320-328$ $\mu \mathrm{m}(324 \pm 4)$; tail appendage length: $36.5-51$ (43.45 \pm 7.27$)$; spicule length: 190-196 $\mu \mathrm{m}(192.66 \pm 3.05)$; spicule width: $14.1-16 \mu \mathrm{m}(15.36 \pm 1.09)$.

Postparasitic juveniles: Dimensions similar to that of adults. With a short caudal appendage.
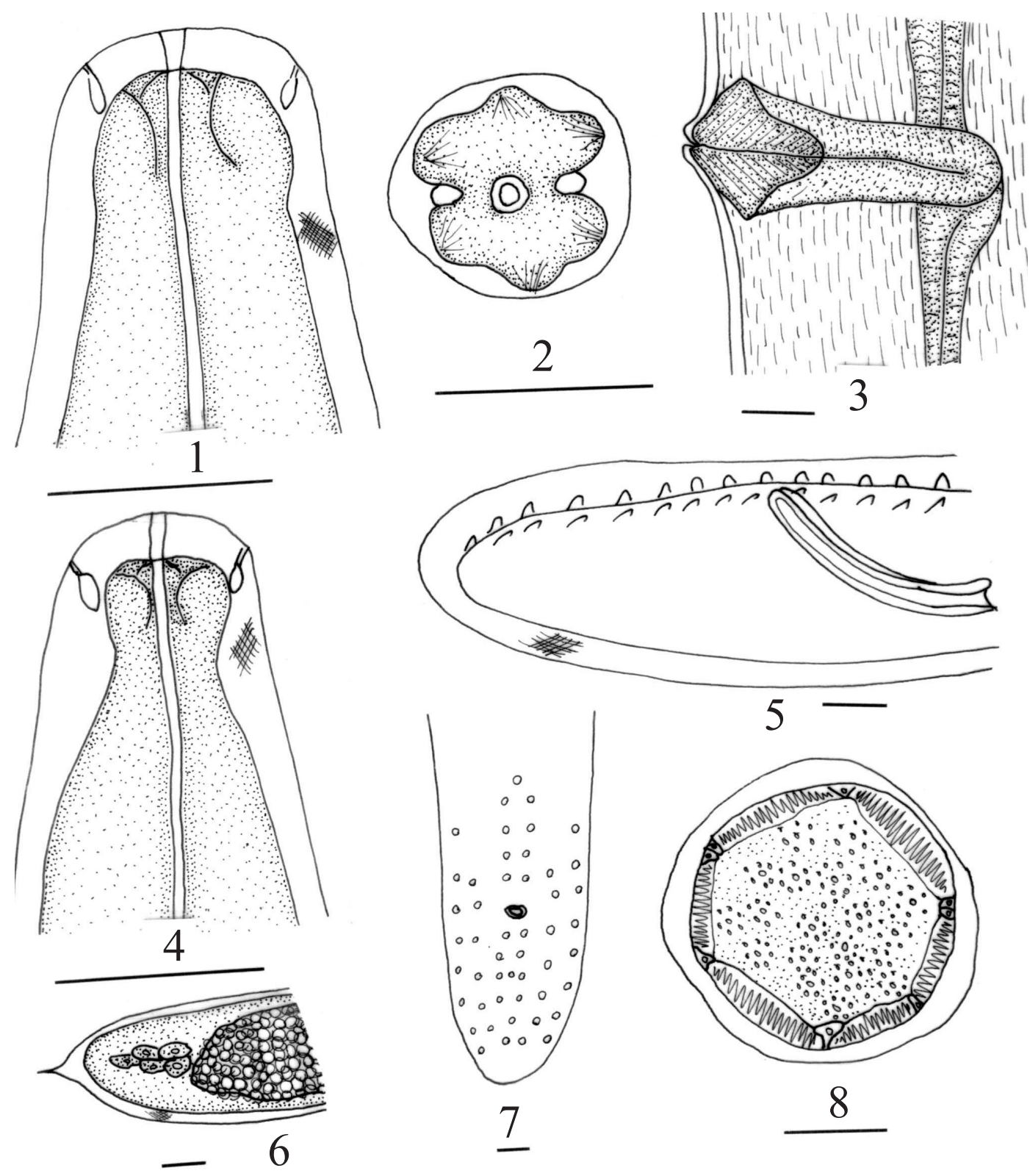

Fig. 1-8. Hexamermis paranaense $\mathrm{n}$. sp. 1, Anterior end of the male; 2, apical view of the head of the male; 3, vagina; 4, anterior end of the female; 5, posterior end of the male, lateral view; 6, posterior end of the postparasitic juveniles; 7 , posterior end of the male, ventral view; 8 , cross section through female at midbody. Bars, $50 \mu \mathrm{m}$. 
Type host. Larvae of Diloboderus abderus (Coleoptera, Scarabaeidae)

Type-material: $\oslash^{7}$ holotype and $\odot$ allotype, ARGENTINA: Buenos Aires, La Plata, field of corn (MLP 5486); paratypes same locality: 160', 20ㅇ, IX-X.2002, N. B. Camino col. (CHC 171).

\section{DISCUSSION}

This species is placed in the genus Hexamermis to posses a horn-shaped vagina, amphids separated from the lateral cephalic papillae (RuBstov, 1978). Postparasitic juveniles of Hexamermis differ from Agamermis Cobb, Steiner \& Christie, 1923 by the tail tip appendage always preserved after final molt (HERNÁNDEZ-CRESPO \& SANTIAGO-Alvarez, 1997).

Hexamermis paranaense $\mathrm{n}$. $\mathrm{sp}$. is characterized by: i) amphids small, amphidial opening pocket-shaped, $i$ ) anterior portion of the vagina muscularized and slightly protruding with a descending branch forming a loop before joining the uterus, and iii) three rows of genital papillae: the ventrolateral divided in two rows with eight papillae in the outer row and with six papillae in the inner one; the ventral row with four pairs and one single preanal papillae, and with two pairs, a triplete, one pair, a single and one pair postanal papillae.

Hexamermis paranaense $\mathrm{n}$. sp. shares the morphology of its vagina ("J" shaped) perpendicular to the longitudinal body axis with: H. albicans von Siebold, 1848; H. arvalis Poinar \& Gyrisco, 1962; H. brevis Hagmeier, 1912; H. cathetospiculae Poinar \& Chang, 1985; H. cavicola Welch, 1963; H. cochlearius; $H$. dactylocercus Poinar \& Linares, 1985; H. elongata Kaiser, 1977; H. gracilis; H. glossinae Poinar et al., 1981; H. hortensis; H. incisura Kaiser, 1977; H. lineata Kaiser, 1977; H. macrostoma; H. microamphidis Steiner, 1925; $H$. ovistriata and $H$. serenensis Hernández-Crespo \& Santiago-Alvarez, 1997.

Hexamermis albicans, a parasite of orthopterans, dermapterans, coleopterans, dipterans, hymenopterans and lepidopterans, is separated by the arrangement of the genital papillae: 4-8 preanal and 5-9 postanal.

Hexamermis arvalis, a parasite of orthopterans and lepidopterans, can be distinguished by having a vagina situated parallel to the longitudinal body axis and in the arrangement of the genital papillae: 3 to 6 irregular and discontinuous rows.

Hexamermis brevis, a parasite of coleopterans, are greater than the body width at the cloaca. Also preanal papillae extended anteriorly along the entire lenght of the spicules and placed in several rows to triplets. The spicules are very short $(50-130 \mu \mathrm{m})$.

Hexamermis cathetospiculae, found in lepidopterans, is distinguished by the size of the spicules (289-334 $\mu \mathrm{m})$ and the genital papillae having three broken (double) rows, lateral double rows containing 20-32 papillae each, extending anteriorly past the cloacal opening, but only half length the spicules, median double row of 20-25 papillae extending anteriorly almost the lateral papillae.

Hexamermis cavicola, a parasite of lepidopterans, is separated by the presence of irregular rows of genital papillae (eigth anal and ten postanal) and female head is tapered more sharply than that of any other of the genus.

Hexamermis cochlearius, a parasite found in orthopterans, can be distinghished by having spicules sligthly curved with a concavity in the internal face of the tip forming a receptaculum. Six rows of genital papillae; a double row of ventrolateral papillae, the external row with 10 papillae and the internal one with 6 ; median ventral rows with a single preanal papilla, two single ones situated in each side of the anus and 7 pairs of postanal papillae.

Hexamermis dactylocercus, found in homopterans, has a tail appendage on the postparasitic, a digit-like appendage on the tails of the adults and the papillae arrangement in 6 or 7 broken rows.

Hexamermis elongata, with unknown host, differs in the size of the spicules $(180 \mu \mathrm{m})$ and the genital papillae have 4 rows: the lateral ones with 6-15 papillae, and the median rows with 8 preanal and 4-17 postanal papillae.

Hexamermis glossinae, a parasite of tsé-tsé, differs from all other species of Hexamermis in the small amphids located on the lateral head papillae; spicules sligthly curved, roughly equal in lenght to the body diameter at the cloaca, male with three double rows of genital papillae; vagina straight.

Hexamermis gracilis, a parasite of coleopterans, is different by having the male three rows of genital papillae with the ventrolateral divided in two rows, the external with 8 papillae and the internal with 4 ; the ventral row with 13 preanal papillae and 14 postanal.

Hexamermis hortensis, found in lepidopterans, is distinguished by the number and arrangement of the male's genital papillae with 8 surrounding the anus, double row of 6 ventrolateral preanal and double row of 15 ventrolateral papillae.

Hexamermis incisura, with unknown host, differs from $H$. paranaense $\mathrm{n}$. sp. by the size of the spicules (110 $\mu \mathrm{m})$, the genital papillae arrangement (11 lateral; the median rows with 8 preanal and 9 postanal) the small amphids situated behind the cephalic papillae and thin at their beginning.

Hexamermis lineata, a parasite of coleopterans, is distinguished in the size of spicules $(185-250 \mu \mathrm{m})$, the arrangement of the genital papillae: 8-25 lateral, and 8-17 postanal in the median rows and by the small amphids situated behind the cephalic papillae.

Hexamermis macrostoma, a parasite found in orthopterans, is separated from $H$. paranaense $\mathrm{n}$. sp. by the stoma size and the genital papillae arrangement in the male, with four preanal rows with 30 papillae and three postanal rows with 24 .

Hexamermis microamphidis, found in hemipterans and lepidopterans, can be separated by having shorter spicules, with a lenght smaller than body diameter at anus level, and the very small amphids.

Hexamermis ovistriata, a parasite of orthopterans, differs from the new species in the arrangement of the genital papillae in the males; six rows: double row of lateral papillae, the external with thirteen papillae and the internal one with twelve irregularly arranged; ventral row with fourteen preanal papillae: a single one at the beginning of the spicules, three pairs, a single one, and three pairs; 
eigthteen postanal papillae: two triplets, five pairs ending with two single ones. Eggs with three longitudinal lines of striations.

Hexamermis serenensis, a parasite of orthopterans, can be distinguished by its long size, the high number of papillae (96-134) in the male distributed in 6-7 broken rows and the morphology of the tail which is conical.

\section{REFERENCES}

Camino, N. B. \& Sтоск, S. P. 1989. Hexamermis hortensis sp. $\mathrm{n}$. (Nematoda: Mermithidae) parásita de larvas de Spodoptera frugiperda (Smith) (Lepidoptera: Noctuidae) en Argentina. Revista Ibérica de Parasitología 49(4):329-333.
Curran, J. \& Hominick, W. M. 1980. Effect of mounting methods on taxonomic characters of adult male mermithids (Nematoda: Mermithidae). Nematologica 26:455-466.

Hernández-Crespo, P. \& Santiago-Alvarez, C. 1997. Description of Hexamermis serenensis sp. n. (Nematoda: Mermithidae) a parasite of Dociostaurus maroccanus (Thunberg) (Orthoptera: Acrididae) in Spain. Fundamental and Applied Nematology 20:37-42.

PoINAR JR., G. O. \& Chang, P. 1985. Hexamermis cathetospiculae n. sp. (Mermithidae: Nematoda), a parasite of the rice stemborer, Tryporyza incertulas (Pyralidae: Lepidoptera) in Malasia. Journal of Nematology 17(3):360-363.

Rubstov, I. A. 1978. Mermithida, Classification, importance and use. Leningrad, Nauka. 207p. (In Russian).

Wouts, W. M. 1981. On the identify of Hexamermis albicans (von Siebold, 1948). Systematic Parasitology 3:127-128.

Recebido em fevereiro de 2007. Aceito em junho de 2008. ISSN 0073-4721

Artigo disponível em: www.scielo.br/isz 